\title{
Rights Of First Refusal in OIL aNd Gas Transactions: A Progressive analysis
}

\author{
ClifFord D. JOHNSON AND DAVID J. STANFORd “
}

This article begins the analysis of rights of first refusal ("ROFR") by providing an historical review of how they have been treated and interpreted by the courts. The analysis continues with an examination of the methods of identifying ROFRs, such as an offer to purchase or a bona fide intention by a party to dispose of its working interest. The authors provide a discussion of the ROFR Notice, discuss package sales and unmatchable consideration, and provide remedies available to a ROFR holder. Throughout the analysis, the authors underscore the importance of drafting proper ROFR clauses at the outset to avoid reasonably foreseeable problems arising later. The authors conclude by drawing implications for the owners of oil and gas properties subject to ROFRs based on the foregoing analysis and provide commentary on the application of ROFRs.
Le présent article analyse tout d'abord le droit de premier refus en offrant un aperçu historique du traitement et de l'interprétation qu'en ont fait les tribunaux. II examine ensuite les modes d'identification du droit de premier refus - offre d'achat ou intention authentigue d'une partie de disposer de son intérét économique. Les auteurs discutent de l'avis de droit de premier refus, de ventes globales et considération sans contrepartie équivalente, et fournissent les remèdes offerts au détenteur d'un droit de premier refus. Tout au long de l'analyse, les auteurs soulignent qu'il importe de formuler correctement les clauses du droit de premier refus pour éviter les problèmes raisonnablement prévisibles. En conclusion, les auteurs traitent des incidences pour les propriétaires de biens relatifs au pétrole et au gaz, et présentent des commentaires sur l'application des droits de premier refus.

\section{TABLE OF CONTENTS}

I. INTRODUCTION ...................... 317

II. General OVERVIEW $\ldots \ldots \ldots \ldots \ldots \ldots \ldots \ldots \ldots \ldots \ldots \ldots$

A. HISTORY, BACKGROUND AND LEGAL

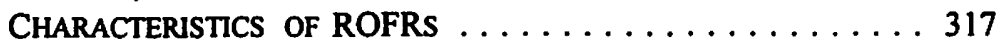

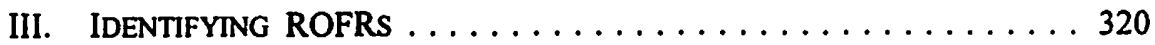

A. TRIGGERING EVENTS AND EXCEPTIONS $\ldots \ldots \ldots \ldots \ldots, 321$

B. IDENTIFYING THE ROFR HOLDER $\ldots \ldots \ldots \ldots \ldots \ldots 328$

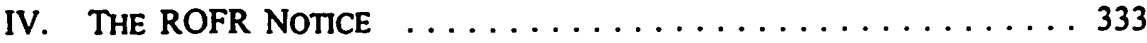

A. THE "Allocation DILEMMA" $\ldots \ldots \ldots \ldots \ldots \ldots \ldots \ldots \ldots \ldots \ldots \ldots \ldots$

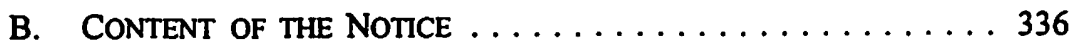

C. ACCEPTANCE BY THE ROFR HOLDER $\ldots \ldots \ldots \ldots \ldots \ldots 337$

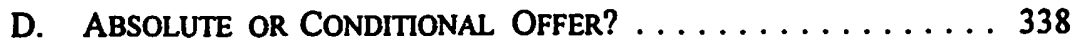

V. AdDITIONAL KEY ISSUES $\ldots \ldots \ldots \ldots \ldots \ldots \ldots \ldots \ldots \ldots \ldots \ldots \ldots$

A. Package Sales $\ldots \ldots \ldots \ldots \ldots \ldots \ldots \ldots \ldots \ldots \ldots \ldots \ldots$

B. UNMATCHABle CONSIDERATION $\ldots \ldots \ldots \ldots \ldots \ldots \ldots 340$

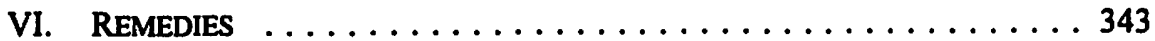

A. Declarations $\ldots \ldots \ldots \ldots \ldots \ldots \ldots \ldots \ldots \ldots \ldots \ldots \ldots$

- Partner, McCarthy Tetrault, Calgary, Alberta.

- Associate, McCarthy Tetrault, Calgary, Alberta. The authors would like to acknowledge with appreciation the valued assistance of Linda Putnam (Associate) and Graham Young (Student-atLaw) in the research and preparation of this article, as well as Mendy Chemos (Partner) for his comments and insight on the Remedies section. 


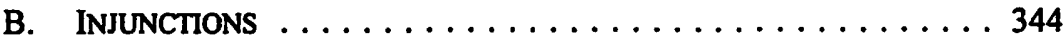

C. SPECIfic PERformance $\ldots \ldots \ldots \ldots \ldots \ldots \ldots \ldots \ldots, 348$

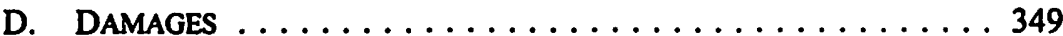

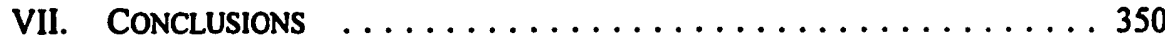

\section{INTRODUCTION}

Over the past several years, the Canadian oil and gas industry has experienced a somewhat frenetic pace of merger and acquisition activity. Aggressive completion timelines are usually involved. In this environment of high stakes and pressure from all sides to "close the deal," none of the parties involved, least of all the proposed purchaser, want to confront obstacles to anticipated and timely completion of the transaction, particularly the spectre of a pre-emptive right such as a right of first refusal ("ROFR").

In an asset, or other applicable, sale transaction, the manner in which a ROFR clause is interpreted and ultimately dealt with can affect the outcome of the entire transaction. Even under more "normal" circumstances, properly interpreting and dealing with the ROFRs that inevitably surface in these transactions can be a challenging exercise. With the ever-increasing complexity and creativity associated with the structuring of oil and gas business transactions, the degree of uncertainty involved in assessing the application of ROFRs to such transactions is enhanced further. Moreover, there is less time available to properly assess them and the potential consequences associated with any failure to satisfy the relevant obligations are greater than ever.

This article involves an historical review of ROFRs and how they are dealt with by the courts, followed by a discussion and analysis of certain key issues involved in the identification and handling of ROFRs in oil and gas related transactions.

\section{General OVERview}

\section{A. History, BaCKGROUND AND Legal Characteristics OF ROFRs}

Many operating and other agreements that include ROFRs were concluded during an era when oil and gas business transactions were more straightforward. Although there are a number of generally accepted business purposes for creating ROFRs in relation to specified properties, it is clear that for whatever reason, the ROFR holder was in the bargaining position of being able to secure a ROFR for the relevant agreement. Whether or not the rationale for its inclusion remain valid at the time a relevant transaction is being considered, once a ROFR has been created, it is virtually impossible to extinguish it while that agreement remains in effect. Since ROFRs will, for the foreseeable future, continue to affect many oil and gas transactions despite the current trend toward excluding them in new operating and similar industry agreements, it is important for those people who are charged with dealing with them to fully understand the basic principles involved and how they are or may be dealt with by the courts. 
At common law, a ROFR attaching to real property is a contractual right which creates no interest in land' until the occurrence of a triggering event, usually the receipt by the vendor of a bona fide offer from a third party which it is prepared to accept. Once such a triggering event has occurred, the option to purchase the subject property in the manner set out in the particular ROFR clause vests in the ROFR holder. This right constitutes an equitable interest in the property where no statutory deeming provision has applied to do so previously. The equitable interest principle was established at the turn of the century in Manchester Ship Canal Company v. Manchester Racecourse Company, ${ }^{2}$ and was subsequently adopted as the law in Canada by the Supreme Court of Canada in its decisions in Canadian Long Island Petroleums Ltd. v. Irving Industries (Irving Wire Products Division) Ltd. ${ }^{3}$ and McFarland v. Hauser and Sunderland. ${ }^{4}$ In Canadian Long Island Petroleums, Martland J. stated that ROFRs cannot be considered interests in land because: (1) specific performance is not necessarily available as a remedy; and (2) ROFRs are personal covenants between parties, that is, they are rights in personam and not in rem.

As noted earlier, once a triggering event has occurred, a ROFR is legally characterized as being in the nature of an option. Although the terms of options, as a general rule, are strictly interpreted, this rule of construction does not extend to the identification of a ROFR in the first instance. In Kopec v. Pyret, the court stated as follows:

the law will not insist on any particular form of words as a pre-condition to creating an enforceable right of first refusal. Where the words used by the parties are capable, on a fair construction, of conveying an intention to give a preferential right to purchase to the promisee without importing any corresponding obligation on the part of the promisee to sell, it is not an impediment to giving effect to the right so created that the parties did not use the exact words "right of first refusal."s

This principle is often referred to as the "fair construction" doctrine, and it has been applied consistently by the courts. In an earlier U.S. case, Brownies Creek Collieries, Incorporated v. Asher Coal Mining Company, ${ }^{6}$ the court observed:

Of course if the holder of the right of first refusal cannot meet exactly the terms and conditions of the third person's offer, minor variations which obviously constitute no substantial departure should be

1 Note that certain provinces, such as Alberta and British Columbia, have enacted statutory provisions making ROFRs equitable interests in land. In Alberta, for example, this was accomplished by the Law of Property Act, R.S.A. 1980, c. L-8, s. 59.1(1), as am. by Real Property Statute Amendment Act, S.A. 1985, c. 48, s. 4(3), which reads as follows:

The following are equitable interests in land:

(a) a right of first refusal to acquire an interest in land.

[1901] 2 Ch. 37 (C.A.) [hereinafter Manchester].

(1974), 50 D.L.R. (3d) 265 (S.C.C.) [hereinafter Canadian Long Island Petroleums].

[1979] 1 S.C.R. 337.

(1983), 146 D.L.R. (3d) 242 (Sask. Q.B.) at 249.

417 S.W. 2 d. 249 (Ky. Ct. App. 1967). 
allowed. And defeat of the right of refusal should not be allowed by use of special, peculiar terms or conditions not made in good faith?

The Alberta Court of Queen's Bench in Two Forty Engineering Lid. v. Platte River Resources Ltd., in consideration of a ROFR and whether or not it applied, confirmed that it remains a cardinal rule of contractual interpretation that the various parts of a particular contract are to be interpreted in the context of the intentions of the parties as evidenced from a consideration of the contract as a whole.

Once it has been confirmed that an enforceable ROFR has been triggered by the owner of the property subject to the ROFR, generally the terms of the ROFR require the owner to issue a ROFR notice to the ROFR holder. At this point, as is the case with options generally, the ROFR holder is then required to strictly comply with its terms. This principle was entrenched in Canadian common law by the Supreme Court of Canada in Pierce v. Empey, ${ }^{9}$ in which the Court stated:

It is well settled that a plaintiff invoking the aid of the Court for the enforcement of an option for the sale of land must show that the terms of the option as to time and otherwise have been strictly observed. The owner incurs no obligation to sell unless the conditions precedent are fulfilled or as a result of his conduct the holder of the option is on some equitable ground relieved from the strict fulfilment of them. ${ }^{30}$

Subsequent cases have consistently found that an existing ROFR was not properly exercised where the ROFR holder did not comply with every term or condition pertaining to its exercise." Furthermore, as will be discussed below, it is apparent that the requirement for strict observance of the terms of ROFR clauses must also apply to the proposed vendor, such that it will also be required to strictly comply with its obligations under the relevant clause.

In summary, when interpreting a ROFR clause, a court will first attempt to ascertain the intention of the parties in its assessment of whether or not a ROFR applies to the transaction at hand, even if this intention is not clearly expressed. If a ROFR is found to apply, the court will then undertake a determination of whether the option terms and conditions have been strictly complied with. Although the focus here is more on the interpretation of ROFRs rather than their creation, it is important to underscore the need for extreme care and attention when drafting a ROFR clause. Undue reliance on

Ibid. at 252 [emphasis in original].

(1996), 41 Alta. L.R. (3d) I (C.A.), aff'g (1994), 26 Alta. L.R. (3d) 183 (Q.B.).

[1939] 4 D.L.R. 672 (S.C.C.).

lbid. at 674.

See in particular Zouvgias v. Chang (1986), 39 R.P.R. 221 (Ont. H.C.J.), where the court held that mere provision of a notice purporting to exercise a ROFR, where it clearly contemplated the requirement to deliver an offer accompanied by a deposit, was invalid; see also Farr v. Attwood (1988), 63 O.R. (2d) 543 (C.A.), affg (1987), 62 O.R. (2d) 306 (Dist. Ct.), where the court held that a ROFR had been properly exercised through delivery of oral notice of exercise because it was unable to conclude that the parties clearly intended that the exercise had to be in written form. 
standard form agreements ${ }^{12}$ can be somewhat risky, although they may well represent a good starting point for the requisite analysis to be undertaken, and in many cases may well prove to be appropriate to the particular circumstances.

A properly prepared ROFR clause must take into account all appropriate exceptions to its application and enforceability which are known at the time it is drafted, as well as any of those which may be considered foreseeable in the context of the property in question. In addition, it requires the drafter of the clause to exercise a high level of attention to detail during its preparation. Anything less may expose the ROFR holder to the very real risk that the pre-emptive right of purchase which it believes it holds will ultimately prove unenforceable or otherwise of little or no benefit to it.

\section{IDENTIFYING ROFRS}

In a typical disposition of oil and gas properties, the process of identifying ROFRs of potential application should involve a review of all relevant agreements and documents, particularly operating agreements, which apply or may at one time have applied to the subject properties amongst the owners and their respective predecessors in interest. During this process, all clauses restricting or potentially restricting a party's right of disposition should be identified and reviewed in the context of the transaction in question. The objective of this exercise is to determine whether, on a reasonable construction, the ROFR provision continues to apply to all or any portion of the properties involved in the transaction. The second task is to determine if the ROFR has been, or may be, triggered as a result of the proposed transaction and, if so, how that may occur. The third task is to determine if there are any potential exemptions from application of the ROFR that may apply in the context of the particular transaction. The final task is to identify the "population" of ROFR holders in the particular circumstances.

Only through this step-by-step process can proper and effective ROFR notices be issued to all parties entitled to receive them. In many instances, this process will be fairly straightforward, particularly where there is only one operating agreement of relevance with a clearly defined chain of title with all parties properly identified. However, this ideal is often not the case and the process can be complicated as a result of prior transactions or poor or incomplete land administration files and records. Some of the relevant issues in this context are discussed further below.

12 Article XXIV in each of the 1974, 1981 and 1990 Operating Procedures prepared by the Canadian Association of Petroleum Landmen (the "CAPL Operating Procedures") contains an election under which the joint owners agree that, subject to certain express exceptions, their rights to dispose of their respective interests are subject to either "Option $A$ ". (prior consent of the other parties to the agreement, not to be unreasonably withheld) or "Option B" (a right of first refusal). 


\section{A. Triggering Events AND Exceptions}

\section{TRIgGerng Events AND How ThEY MAY APPLY}

At a theoretical level, the events which will trigger the applicability of a ROFR can be as numerous or as few, as broad or as narrow, as the drafters of each particular ROFR provision may determine. For example, the ROFR clause in two noteworthy cases provided that the ROFR came into effect upon the receipt by one party of "a bona fide offer ... which it [was] willing to accept."13 This language was commonly found in ROFR clauses which began to emerge in significant numbers in the 1950s and 1960 s in the Canadian petroleum industry, and the resulting case law which culminated in the Canadian Long Island Petroleums decision gave these words a broad interpretation. $^{14}$ Today, due primarily to the widespread use and application of the various CAPL Operating Procedures, the typical language has been modified somewhat. Both the 1974 and 1981 CAPL Operating Procedures provide in Article XXIV that a party "shall not assign, sell or dispose of any of its participating interest in the joint lands" without either first obtaining the consent of the other parties to the agreement, or if the parties so elect, first complying with a detailed ROFR procedure. In the 1990 CAPL Operating Procedure, Article XXIV was amended slightly to require that "a party shall not dispose of any of its working interest, whether by assignment, sale, trade, lease, sublease, farmout or otherwise, without first complying with" whichever of these two options the parties have selected as applying in the particular circumstances.

Nonetheless, the principles established in Canadian Long Island Petroleums remain the law in Canada today. Thus, the preferred course of action is to initially assume that any bona fide intention by a party to dispose of its working interest will, in the face of a properly and clearly structured ROFR clause, and absent an available exception, result in an option crystallizing in favour of the ROFR holder to acquire the interest on substantially the same terms as those proposed by the disposing party or that are contained in an offer that has been received by that party which it is willing to accept.

\section{ROFRS AND CONDITIONAL OFFERS}

The law is less clear with respect to whether an offer to purchase subject to the satisfaction of certain conditions will trigger an applicable ROFR. Within this question lies the more narrow issue of whether an offer made conditional upon the non-exercise of the ROFR will trigger the ROFR. Two distinct schools of thought have evolved on this point. One such school applies a broad, purposive construction of ROFR clauses and argues that a ROFR which is triggered upon the receipt by a vendor of an offer which it is willing to accept is nevertheless triggered where the offer states that it is

Canadian Long Island Petroleums, supra note 3 at 267; and Budget Car Rentals Toronto Led. v. Petro-Canada Inc. (1989), 60 D.L.R. (4th) 751 (Ont. C.A.) at 752 [hereinafter Budget Car Rentals].

14 For example, in Canadian Long Island Petroleums, the working interest owner cum proposed vendor was the party who made the offer to sell, rather than, as was typically the case, being the recipient of an offer to purchase. The court held that this artificial distinction was not sufficient to avoid the application of the ROFR. 
made subject to the non-exercise of the ROFR. This view finds support in a 1982 case out of British Columbia, Lomac Holdings Ltd. v. Prijatelj, ${ }^{15}$ where the British Columbia Supreme Court was faced with a situation where, in the course of negotiations for the purchase and sale of a ROFR-encumbered property, the vendor made a counter-offer which was accepted by the purchaser "subject to expiry of fifteen days right of first refusal."16 The language of the ROFR clause in question clearly contemplated that if the vendor received a bona fide offer which it wanted to accept, it was obligated, prior to accepting such offer, to deliver a copy of it to the ROFR holder. The ROFR holder then had the right, within fifteen days of receipt thereof, to deliver its own offer to the vendor on the same terms and, if it did so, the vendor was required to "accept the [ROFR holder's] offer and refrain from accepting the Third Party Offer." 17 McLachlin J. (as she then was) held that (1) the contract containing the ROFR was a "commercial document which should be interpreted in a large and fair sense so as to give effect to the manifest intention of the parties at the time of contracting" and (2) "[t]he fact that the vendors agreed to sell to the purchasers should [the ROFR holder] elect not to exercise its right of first refusal [did] not violate the terms of the right of first refusal."18

With respect, it is submitted that this ruling appears to disregard the fact that ROFRs are one of a select few contractual arrangements which have been treated by the courts in ways that are distinct from those applied to standard "commercial documents." Once it has been determined, using the "large and fair" interpretation to which McLachlin J. refers, ${ }^{19}$ that an enforceable ROFR attaches to a particular property, the provisions of that particular ROFR are then to be strictly construed. In most instances this strict construction is applied against the ROFR holder insofar as its compliance with the ROFR notice is concerned. However, for obvious reasons of fairness and certainty, a contractual provision should be construed equally in respect of all of the parties to the contract. Applying this principle to the ROFR clause in Lomac Holdings, it is difficult to conceive of a strict interpretation of its language resulting in a conclusion other than one in which the vendor violated the terms of the ROFR by entering into a conditional agreement before providing a copy of the unaccepted offer to the ROFR holder.

The second school of thought supports this strict interpretive approach and finds acceptance in a more recent case out of British Columbia, Stellar Properties Lid. v. Botham Holdings Ltd. ${ }^{20}$ There, the British Columbia Court of Appeal appears to have disregarded Lomac Holdings and distinguished between an offer that a vendor is willing to accept and one which has already been accepted by the vendor, subject to the condition of the ROFR being waived. Speaking for the court, Southin J.A. held as follows:

(1982), 38 B.C.L.R. 238 (S.C.) [hereinafter Lomac Holdings].

lbid. at 239.

Ibid. at 241 [emphasis added].

Ibid.

Ibid.

(1990), 47 B.C.L.R. (2d) 260 (C.A.) [hereinafter Stellar Properties]. 
While I can see the argument that, in practical terms, there is no difference to the lessee between an offer not accepted and an offer accepted subject to the right of first refusal, 1 am of the opinion that the law is not well served when plain English words are given a gloss to suit a notion of practicality. The crucial words are words of futurity - they contemplate a lessor not yet bound in any way to any proposed purchaser. In my opinion, as between lessor and lessee, this lessee was entitled to say, "You have not complied with the terms of my right" and to say to the proposed purchaser, "My right of first refusal is not extinguished by your offer and its acceptance for the lessor had no right to accept anything from you when he did. And if you had read the lease you would have known that."21

This approach has been criticized by Mills \& Beck who have pointed out the similarity between the language of the ROFR clause at issue in Stellar Properties and Article XXIV of both the 1974 and 1981 CAPL Operating Procedures. They suggest that the result of this case is "exceedingly impractical" and note that it is not consistent with the common oil and gas industry practice at present where a vendor and purchaser enter into a purchase and sale agreement subject to existing ROFRs and then attach a copy of such agreement to the ROFR notices sent out. ${ }^{22}$ While both of these points have validity from a practical perspective, there can be no assurance that they would prevail in court over an argument supporting the historical predisposition of the courts to apply a strict construction of ROFR clauses.

Therefore, when considering the application of a ROFR clause and its effect in the context of a particular transaction, specific compliance with the terms of the ROFR clause to the fullest extent reasonable is clearly the best approach. Anything less means acceptance of risk that either the ROFR holder's exercise of the ROFR might be invalid or that the vendor's notice is defective and therefore does not constitute notice at all. The potential consequences of either eventuality are, needless to say, of significant concern in the context of an expedited transaction.

\section{EXCEPTIONS TO ROFR PROVISIONS}

Typical oil and gas industry ROFR provisions, such as those found in the CAPL Operating Procedures, often contain exceptions to their application for assignments, sales, dispositions or other conveyances to affiliates, conveyances of all or substantially all of a party's assets (or assets in a particular province) or amalgamations. Generally speaking, business combinations such as amalgamations, plans of arrangement or similar "corporate" reorganizational transactions completed pursuant to statutory provisions should not trigger or violate standard ROFR clauses. However, some older operating agreements do not include exceptions for such corporate level transactions and one cannot assume, apart from a specific review of the ROFR clause in question, that a particular ROFR will or will not be triggered by that transaction.

$21 \quad$ Ibid. at 271-72.

22 D. Mills \& B. Beck, "Rights of First Refusal" (paper presented at the Insight conference entitled "Exercising Due Dilegence in Oil and Gas Property Transactions," Calgary, 24-25 February 1998), (Toronto: Insight Press, 1998) at 235. 
Notwithstanding the absence of a specific exception, the most obvious argument to make in the case of a statutory amalgamation is that no transfer of property occurs, which is normally a requirement for a ROFR to be triggered. For example, the Canada Business Corporations $\mathrm{Act}^{23}$ implies that no "sale" occurs through an amalgamation, and therefore "the property of each amalgamating corporation is simply merged with and continues to be the property of the amalgamated corporation." ${ }^{24}$ ROFRs will, however, continue to burden the property held by the newly amalgamated entity.

An American case supports the principle that these types of transactions should not trigger ROFRs. In Torrey Delivery, Inc. v. Chautauqua Truck Sales and Service, Inc., the court said:

Ownership of capital stock being distinct from ownership of corporate property, it follows that the sale of such stock is not a sale of corporate property. ${ }^{25}$

However, it is less clear whether the same principle could be applied to find that a distribution of property made in the course of the dissolution of a corporation is not a "sale," and that it therefore does not trigger an applicable ROFR. While several U.S. statutes and court decisions seem to support this position, ${ }^{26}$ there is little if any Canadian jurisprudence on point, although at least one commentator believes that a Canadian court would likely follow the U.S. approach. ${ }^{27}$

Vendors sometimes dispose of assets by "rolling" them into a wholly owned subsidiary and then transferring the shares of the subsidiary to a purchaser. This is a rather simplistic description of what is commonly referred to as a "butterfly transaction." While butterfly transactions are usually employed for tax purposes, this is not always the case. Absent a true bona fide business purpose for a particular butterfly transaction (i.e., that it has not been employed simply to defeat an applicable ROFR), it would likely be ineffective as a method to avoid triggering the ROFR.

It has been argued that "purchase" butterfly transactions are not subject to ROFR transactions as they ultimately involve a sale of shares, which is usually an exempt transaction under most ROFR provisions. However, purchase butterflies are not permitted for tax reasons at this time. In any event, a basic principle or tenet in consideration of ROFRs is that one cannot do indirectly what one cannot do directly. To deny the holder of a ROFR the opportunity to exercise its right of purchase in circumstances such as butterfly transactions would defeat one of the basic purposes of the right, which is to allow a joint owner the opportunity to have some control over who it does business with. This principle has taken on an enhanced importance with the emergence of environmental protection legislation which involves the potential

R.S.C. 1985 , c. C-44, s. 186(b).

R. Flannigan, "The Legal Construction of Rights of First Refusal" (1997) 76 Can. Bar Rev. 1 at 19.

366 N.Y. S. 2d 506 at 510 (CL. App. 1975).

Flannigan, supra note 24 at 20.

Ibid. 
imposition of joint and several liability on past and present owners of property for onsite or off-site contamination which has resulted from operations carried out by one or more of the owners on jointly owned lands.

However, if the transaction has a legitimate business purpose, and if, in appropriate circumstances, there is at least a meaningful period of time between the effecting of the corporate reorganization and the sale of the shares of the resulting subsidiary whose assets are encumbered by a ROFR, the transaction should not be found to have violated the ROFR provision and may also have satisfied applicable tax requirements. In this context, the "behaviour" of the purchaser of the shares of the resulting subsidiary may also be relevant to the question of the bona fides associated with the particular transaction.

In addition, although a share transaction may possibly have the effect of transferring the subject property without triggering applicable ROFRs, it has been suggested that this result is actually "a natural consequence of separate entity status. The subject property is owned by the corporation both before and after the transfer of its shares." 28 However, the validity of this argument would appear to depend largely on the existence of an applicable exception for each specific step of the transaction, in addition to the exercise of good faith on the part of the vendor and the prospective purchaser, to avoid triggering an otherwise applicable ROFR. Unfortunately, prospective ROFR holders often fail in their negotiation of ROFR provisions to appreciate the importance of identifying the entire potential array of transactions that should be subject to the ROFR, such that it may not apply when the ROFR holder might otherwise believe that it does.

Depending on the particular circumstances involved, an argument may exist where a ROFR, which prima facie applies to a transaction and where no express exception applies, was never intended to apply to a transaction of the nature under consideration, possibly due to some unusual or unique feature involved. The obvious example would be, as discussed above, a statutory amalgamation of one corporation with another corporation whose property is subject to a ROFR in favour of a third party. It could likely be argued successfully in that circumstance that the parties would not have intended for the ROFR to apply in any event. This sometimes "unspecified" exception is really nothing more than an observed interpretation of the intention of the parties from the words they have used to describe the ROFR and the nature and type of transactions to which the ROFR was intended to apply.

Notwithstanding the presence of valid and reasonable arguments that may be made to the effect that it was not contemplated that a particular transaction would be subject to a ROFR, a ROFR holder might successfully argue that (1) the steps of a butterfly or other share transaction must be looked at as a whole, and (2) if the overall result of the completion of the transaction is really no different than would have been the case if the property had simply been conveyed directly to the purchaser, the ROFR should be considered to have been triggered. As the purchase price one would be willing to pay in a share transaction is usually quite different from that which one would be 
willing to pay in an asset transaction, difficult and not easily reconcilable questions arise about how to properly comply with the ROFR.

The suggestion that the issue is really one of substance over form has received recent support in GATX Corp. v. Hawker Siddeley Canada Inc., ${ }^{29}$ which was recently followed in the decision of Nuance Global Traders (UK) Ltd. v. Agra Inc. ${ }^{30}$ In the former case, Hawker Siddeley and GATX were parties to a shareholders' agreement under which they agreed that neither of them would "sell or otherwise dispose of" any of their respective shareholdings in their jointly owned subsidiary, CGTX, to a third party without first offering the shares to the other on the same terms and conditions contained in the offer from the third party. This agreement also contained a clause which provided that the ROFR did not apply to a "transfer of common shares by either party to another corporation which is affiliated with ... either of the parties hereto." Hawker Siddeley later decided that it wanted to sell its shares of CGTX and entered into discussions with GATX, but was not satisfied with the price that GATX was offering. Hawker Siddeley then reached an agreement with Procor Limited to effect a transaction which would result in the transfer of its shares of CGTX to Procor Limited at a price substantially higher than the best offer from GATX. After consulting with Procor Limited and its financial advisors, a structure was created involving a series of transactions which were apparently designed, for the most part, to effect a transfer of the shares to Procor Limited without triggering the ROFR. Pursuant to its agreement with Procor Limited, Hawker Siddeley transferred its shares in CGTX to a newly incorporated subsidiary, which prima facie did not trigger the ROFR. However, Hawker Siddeley then proposed to declare a dividend of the shares of this subsidiary to its shareholders, following which Procor Limited would make an offer to the shareholders for these shares of the former subsidiary pursuant to Ontario's takeover bid legislation. GATX brought an action seeking declaratory and injunctive relief along with specific performance of the ROFR. The court granted specific performance of the ROFR in favour of GATX and in this regard stated as follows:

In my view the effect of the Procor Agreement must be looked at in its entirety and judged as a whole. Its objective is to remove the Hawker Siddeley interest in CGTX from the hands of Hawker Siddeley and the Hawker Siddeley shareholders and to transfer that interest into Procor's hands. The proposed transaction cannot be subdivided into isolated parts - each one of which, if considered out of context, might appear individually to be benign - and given effect to on that basis, given the existence of the Right of First Refusal which clearly attaches if the transaction is viewed as a whole. ${ }^{32}$

The court in this case made two additional significant findings which are worth noting here. First, the court cited Canadian Long Island Petroleums, as authority for the proposition that, "as a matter of straight contract law," the ROFR precluded Hawker Siddeley "from proceeding with the proposed transaction without first putting to GATX

(1996), 27 B.L.R. (2d) 251 (Ont. C. (Gen. Div.)) [hereinafter Hawker Siddeley]. [1998] OJ. No. 462 (Gen. Div.) (QL).

Hawker Siddeley, supra note 29 at 260-61.

Ibid. at 275. See also Mills \& Beck, supra note 22 at 60-63. 
the option of purchasing Hawker Siddeley's shares in CGTX." ${ }^{33}$ Secondly, the court confirmed the principle that "the grantor of a right of first refusal must act reasonably and in good faith in relation to that right, and must not act in a fashion designed to eviscerate the very right which has been given." 34

Glimmer Resources Inc. v. Exall Resources $L t d^{35}$ is a more recent decision, also from the Ontario Court of Justice (General Division), which sheds additional light on the issues raised in Hawker Siddeley. In this case, Glimmer Resources and Exall Resources were the only parties to a joint venture agreement respecting the operation of a mining property. The joint venture agreement contained a right of first refusal restricting either party from "assigning, selling or otherwise transferring any interest it may have under this agreement to any third party." ${ }^{36}$ Kent, a principal shareholder of Glimmer Resources, agreed to sell his shares to a third party, Matachewan Consolidated Mines Limited ("Matachewan").

The court considered its earlier decision in Hawker Siddeley and, in distinguishing the case before it from Hawker Siddeley on its facts, held that the sale by Kent to Matachewan did not contravene the ROFR contained in the joint venture agreement. In particular, the court noted that: (1) Kent's sale of his shares appeared to have a reasonable business purpose; (2) the transaction was not structured in a way to avoid the ROFR provision contained in the joint venture agreement; (3) the ROFR provision contained in the joint venture agreement specifically dealt with a transfer by one of the parties thereto of "any interest it may have under this agreement to any third party"; and (4) Kent was not a party to that agreement. ${ }^{37}$ Because the interests under the joint venture agreement did not change and the ROFR clause did not, on its face, appear to apply to a transfer of anything other than these interests, the transaction did not fall within the scope of the ROFR and thus the application of Exall Resources to set aside that transaction failed.

The decisions in both the Hawker Siddeley and Glimmer Resources cases emphasize the fact that the courts will not accept transactions which are contrived by parties to do indirectly what they cannot do directly, but they will allow transactions to proceed which have legitimate business purposes and which are not simply structured so as to avoid another party's pre-emptive rights. Such purposes may well include tax planning and the structuring of transactions to avoid potentially adverse tax consequences. In any event, as Glimmer Resources has clearly confirmed, the potential effectiveness of these transactions is significantly enhanced by clear and comprehensive ROFR language which contemplates reasonably foreseeable occurrences such as a change in control of a corporate shareholder as triggering the ROFR where this result is desired. Conversely, if this result is not intended, a specific exception to application of the ROFR can be included for the avoidance of doubt.

$3 \quad$ Hawker Siddeley, ibid. at 276.

$14 \quad$ lbid.

is (1997), 35 B.L.R. (2d) 297 (Ont. Ct. (Gen. Div.)) [hereinafter Glimmer Resources].

3. lbid. at 301 .

"See also Mills \& Beck, supra note 22 at 63-65. 


\section{B. IDENTIFYING THE ROFR HOLDER}

\section{NON-WORKING INTEREST OWNERS}

An additional issue which has received limited academic commentary or judicial consideration is whether the holder of a non-working interest (such as a gross overriding royalty or "GORR") in lands which are subject to a ROFR is entitled to the same benefits as those parties holding working interests in those lands, particularly where a common agreement is involved. This situation could arise where a farmor under a farmout agreement is in an override position in an arrangement that includes a ROFR, or where a working interest owner in lands subject to a ROFR has converted its interest into an overriding royalty, but with the ROFR remaining intact. One author ${ }^{38}$ has argued that ROFRs should be construed as applying to working interests only and, therefore, a disposition by a non-working interest owner of this non-working interest would not trigger the ROFR in favour of the working interest owners. He writes:

The one purpose of facilitating a party's increasing his interest in properties with which he is both familiar and involved would be furthered by treating the provision as applicable and authorizing him to buy the override or production payment which the other party desires to sell. On the other hand, because the owner of an override or production payment ordinarily has no operating rights or responsibilities, the more significant purpose of the provision (that of giving each party some measure of control over who the operating parties shall be) would not be served by construing the preferential purchase right provision as according to the one party the right to buy the nonoperating interest which the other party desires to sell. ${ }^{39}$

This is a logical premise, and one that can presumably also be applied to conclude that a non-working interest owner is not a party properly entitled to receive a ROFR notice under a ROFR triggered by a working interest owner. In support of this position, a recent article ${ }^{40}$ has suggested that, since the ROFR clauses contained in the CAPL Operating Agreements contemplate a sharing of the ROFR property where two or more ROFR holders elect to exercise their rights, a potentially impossible scenario could result if non-working interest owners were allowed to elect as well. In particular, it is stated that "since it is self-evident that the working interest in a property can never add up to more than $100 \%$, it should equally be true that only working-interest owners are entitled to receive ROFR notices under the CAPL forms." ${ }^{41}$

It is submitted that these should be very persuasive arguments before a court faced with ruling on this issue. However, there are some possible nuances within the issue which require a somewhat deeper analysis, depending to a large extent on the possible construction of the ROFR clause. For example, should a distinction be made between a non-convertible non-working interest and a convertible non-working interest which

J.S. Sellingsloh, "Preferential Purchase Rights" (1966) 11 Rocky Mtn. Min. L. Inst. 35.

Ibid. at 48.

Mills \& Beck, supra note 22.

Ibid. at 245. 
has not been converted into a working interest at the time the ROFR is triggered? Furthermore, should the logic in the foregoing arguments be ignored and a non-working interest owner be allowed to exercise a ROFR in respect of the entire working interest where none of the other joint working interest owners elect to step up their interests?

With respect to the first of these questions, a good argument seems to be that no technical distinction should be drawn between a convertible and non-convertible nonworking interest; however, practically speaking there would be no impediment to the holder of a convertible interest electing to convert its interest to a working interest (assuming it is entitled to do so at the relevant time), thereby entitling it to acquire an interest in the ROFR property proportionate to this converted working interest. This begs the further question of whether a holder of a convertible non-working interest is therefore entitled to receive a ROFR notice from the vendor, because how would it otherwise learn of the proposed transaction? Would a court be sympathetic to an argument by such a party that, because it had the ability to instantly convert its nonworking interest into a working interest, the vendor had a duty to advise it of the proposed sale, whether by the issuance of a ROFR notice or otherwise?

The only reliable response to all of these questions, albeit only a partial one, is that the result in each case would almost certainly turn on an interpretation of the particular ROFR clause involved. Insofar as the ROFR clauses in the various CAPL Operating Agreements are concerned, the key consideration in each of the different forms appears to be that the proposed vendor's obligation to notify of its intention to sell arises only in favour of the other parties to the agreement. Accordingly, since by their very nature operating agreements deal primarily with the concerns of working interest owners, it is at least arguable in some circumstances that a non-working interest owner is in a different position than the working interest owners and therefore should not be entitled to receive a ROFR notice. It also follows, therefore, that a holder of a convertible GORR may also not be a proper party to receive a ROFR notice, although its position is clearly enhanced over its non-convertible counterpart. However, based on the principle that the benefits of a contract flow with its burdens, it remains arguable that a notice should be delivered to the holder of a convertible GORR, particularly where that holder could convert its GORR to a working interest prior to the occurrence of the triggering event.

With respect to any suggestion that a royalty interest holder should be entitled to a ROFR notice, and the right to elect to acquire a working interest ahead of a proposed purchaser in circumstances where all of the other working interest owners have waived their rights under the ROFR, it is our view that this would impose an inordinate hardship on the parties to the potential transaction, particularly in determining when they may legitimately proceed to close the transaction between them. The generally accepted approach to interpreting ROFR clauses would seem to require the rejection of any scenario under which a ROFR might exist in favour of a party depending on whether or not certain contingencies occur after it has been triggered. The better approach appears to be that the total "population" of parties entitled to receive a ROFR notice is to be ascertained as at the time the triggering event occurs, and that, for the purposes of that particular ROFR at that point in time, this "population" cannot change. 
Moreover, in this scenario, there may in effect be a new transaction occurring between a working interest owner and other parties which itself may be a notifiable transaction in favour of the other parties to the operating or other agreement under the ROFR provisions.

At this time it is far from clear how this situation will be handled by the courts in Canada should it arise, but it does appear to represent an undue interference in commercial transactions and an interference with one's ability to deal with one's property. The authors were unable to find any case authority in either Canada or the United States which has dealt directly with this issue. However, a fairly recent Texas case, TransAmerican Natural Gas Corporation v. Finkelstein, ${ }^{42}$ involved a claim by a royalty owner to participate in settlement proceeds arising out of a take-or-pay contract and bears a possible analogy to the issue under consideration. In this case, the Court of Appeals of Texas (Fourth District) was faced with a situation involving a royalty owner claiming an entitlement to participate in proceeds from both a gas purchase contract and a settlement agreement to which it was not a party. The majority of the court held that "a royalty owner is not entitled to settlement proceeds from a take-or-pay contract absent lease language to that effect." ${ }^{43}$ Although the questions of entitlement to a ROFR notice and to take-or-pay obligations under a gas purchase contract are obviously unrelated, a possible analogy may be made to the principle reflected in this case that unless the agreement expressly provides otherwise, the only benefit reserved to a non-working interest holder under a standard operating agreement is for the payment of its royalty; it is not otherwise entitled to participate in any of the benefits otherwise reserved under the agreement for working interest owners.

Therefore, it appears clear that if a non-working interest owner is intended to have ROFR rights, appropriate provisions must be included in the ROFR clause contemplating any or all of the scenarios discussed above. As a ROFR is a creature of contract, a ROFR will take whatever shape its creators give it. Accordingly, caution must be taken at the drafting stage to avoid using vague and ambiguous language, because in the absence of concise language which clearly provides for a ROFR to apply in non-traditional or unusual circumstances, the courts will likely adopt reasoning consistent with a strict interpretation of ROFRs in the context of their predominant purposes.

\section{DeEming Provisions}

An issue which has received little, if any, consideration is the effect of certain deeming provisions in documents on identifying potential ROFR holders at the outset of a typical transaction. One example is the September 1, 1993 Industry Agreement (the "Industry Agreement"). As experienced oil and gas counsel are aware, the Industry Agreement deemed that certain types of agreements - many of which contain ROFRs - were deemed amended effective 15 November 1993 to incorporate a new assignment procedure to replace the cumbersome and often delayed assignment and novation 
process. Assignment and novation agreements often remained unsigned for years despite the fact that several subsequent transactions involving the same interests may have been concluded during that time, creating difficult and complicated land administration issues that could easily have been avoided.

The assignment procedure provides that an assignment from one party to another of an interest in a master agreement is deemed to be binding on the assignee on the first day of the second month (the "Binding Date") following delivery of a notice of assignment in the prescribed form to all third parties, provided that no third party objects in writing to the assignment before that time. The Binding Date represents the date on which: (1) the assignee is officially recognized as a party to the master agreement by the other parties to that agreement, and (2) the assignor is deemed to be removed from the master agreement (effective as of the effective date of the transfer). Where is a ROFR is triggered within the period of time between the effective date of the transfer and the Binding Date under a notice of assignment, a question that arises is, as between the assignor and the assignee, which of them is properly entitled to receive the ROFR notice? Arguably, where the ROFR notice is delivered to the assignee prior to the Binding Date (on the assumption that the transaction closed), and subsequent to this a valid objection is raised which prevents the Binding Date from occurring, the assignor might be in a position to argue that the notice period respecting its interest has not yet commenced and that it was, and is, entitled to a ROFR notice from the disposing party.

Clause 2404 of the 1990 CAPL Operating Procedure poses similar questions, especially if the parties to the agreement have selected Alternate "B," which provides that third parties to an assignment are deemed to have executed a novation agreement, "unless, within ninety (90) days of the receipt of that agreement, one (1) or more of the other parties have advised the parties, by notice, that they are not prepared to execute that agreement and the reasonable objections they have to that agreement." Clause 2404 of each of the 1974 and 1981 CAPL Operating Procedures poses a similar problem.

While the likelihood of the above scenario taking place may be remote, the point the authors wish to emphasize is that whenever deeming provisions of any kind apply, there may be uncertainty involved in defining the population entitled to receive a ROFR notice, particularly where an objection was appropriately raised but did not find its way into the file being reviewed.

\section{ROFRS IN UNDERLYING AGREEMENTS}

In the oil and gas industry, ROFRs can be found in a wide variety of agreements, such as joint operating agreements, unit operating agreements, agreements respecting the construction, ownership and operation of gathering and processing facilities, and farmout agreements. ${ }^{44}$ 
On occasion, these master agreements have been superseded in whole or in part by a subsequent or further agreement respecting the same lands. A common example occurs when certain zones forming a portion of lands which are subject to a joint operating agreement containing a ROFR are unitized with other contiguous zones outside the scope of the joint operating agreement, and the unit operating agreement governing the newly formed unit does not contain a ROFR.

In such circumstances, an issue occasionally arises as to the enduring effect of the ROFR provision in the pre-existing joint operating agreement. In other words, is the ROFR in the original agreement superseded as to the unitized zone by the unit operating agreement and therefore no longer operative? Apart from express provisions to the contrary agreed to by all ROFR holders, the authors believe the better view to be that the ROFR continues in effect in accordance with its terms despite the presence of the new agreement. This is particularly true in a unit situation, as the underlying operating agreement will normally become operative in respect of the unitized zone if the unit agreement terminates. As such, a ROFR applying to all zones would normally continue to apply to all zones even after unitization of a particular zone absent express language to the contrary. Even then, all affected parties, including the ROFR holders, would require an executed unit agreement or other such agreement for the exemption to have any legal effect.

\section{BENEFICIAL OWNERSHIP ISSUES}

A fairly common situation faced by parties to a proposed transaction is the existence of a participation agreement between one party, whose recognized interest in a property is subject to a ROFR under an operating or similar agreement in favour of the other parties, and another party whose interest is represented by that first party. This participation agreement may provide certain rights and benefits to the participant who is not recognized under the applicable operating or other agreement, and who must therefore rely on the party so recognized.

This situation raises a myriad of potential issues. For example, if the participation agreement was entered into after the ROFR provision was adopted, it may be necessary to consider whether the party to the main agreement secured a consent or waiver from the other parties to allow it to enter into the participation agreement in the first instance, as this will likely have represented a disposition subject to the ROFR. If it did not, there may have been a breach of the ROFR provision that remains unresolved. If the consent or waiver was secured, an examination of it should be undertaken to determine what it encompassed. Did it address only the disposition to the participants, or did it also contemplate a waiver in respect of subsequent dispositions of the same participating interest, whether back to the party recognized under the relevant agreement or to third parties? Most ROFR clauses would not accept the participation agreement as an exempted transaction, and caution obviously needs to be exercised in structuring and dealing with participation agreements in the face of otherwise applicable ROFRs.

From the perspective of a participant under the participation agreement who wishes to dispose of its interest, the situation gets very complicated due to the fact that it is not 
recognized under the main agreement. Most recipients of a ROFR notice from an unrecognized party will not accept that notice as being effective for any purpose. The recognized party under the main agreement could theoretically issue the notice on behalf of the disposing participant, but may not have the ability to deal directly with the property should it be exercised.

An additional concern is that a second ROFR may exist in the participation agreement which was negotiated to protect the parties, particularly the recognized parties, from unwanted participants assuming rights under the participation agreement. Moreover, there is a solvency risk being assumed by the recognized participant in respect of the non-recognized participant, as it may have obligations to the other parties to the main agreement which it cannot satisfy if a participant defaults or loses its interest in a foreclosure or similar situation.

Assuming that the participation agreement was established in a manner that did not violate the ROFR provision, the prudent course of action by a participant wishing to dispose of its interest would likely be to cause a ROFR notice to be issued by the party represented under the main agreement. As that party's interest will be subject to the participation agreement, there may be an issue raised by the ROFR holders as to the effectiveness of the ROFR notice and to the propriety of requiring them to then become subject to the participation agreement.

Often a participation agreement will include a "promote" in favour of the recognized party, which it will not likely want to give up. However, a ROFR holder may, and perhaps rightly so, take the view that the promote is not applicable to it. However, if it or its predecessors in interest consented to the participation arrangement in the first instance, its ability to challenge the arrangement will be significantly impaired. Obviously, more complex problems arise when a participation agreement has not been disclosed to a ROFR holder and transactions take place behind the recognized party.

\section{THE ROFR NOTICE}

\section{A. The "Allocation Dilemma"}

The phrase "allocation dilemma" was coined by Cliff Johnson in reference to the situation faced by all stakeholders where a ROFR prima facie applies only to a portion of the properties involved in a transaction. The usual contractual obligation is for the vendor to designate the purchase price that is applicable to ROFR-encumbered properties. However, in a "package" sale transaction, there is often no clearly defined purchase price to refer to for the specific properties.

The interests and objectives of the various parties, i.e., the vendor, purchaser and ROFR holder, are quite diverse and not easily reconciled. The vendor has evidenced an intention to dispose of a package of property and presumably will have negotiated an acceptable price for the package taken as a whole. It will not likely care about the price being paid for individual properties, as long as its overall target price is met. Moreover, apart from any duty it may have to the ROFR holder to satisfy any 
obligations applicable under the relevant ROFR provision, the vendor may not be particularly concerned if the property goes to the prospective purchaser or to the ROFR holder, unless the entire transaction is somehow adversely impacted as a result. The purchaser has obviously negotiated a deal for the property package as a whole and likely does not want the ROFR holder to acquire the ROFR-encumbered properties which may well be key to the entire transaction. The ROFR holder simply wants its opportunity to acquire the property at a fair price through the exercise of its ROFR should it wish to do so.

The first order of business is to determine if there are any exceptions to the application of the ROFR by reason of the nature of the transaction in question. If not, the challenge then presented to the vendor and the purchaser is to allocate a fair portion of the overall purchase price to the ROFR-encumbered properties that will satisfy the disclosure obligations to the ROFR holder. In these circumstances, the vendor is the party with the contractual duty to the ROFR holder. However, this is not to say that the purchaser is without duty or obligation to the ROFR holder. Cases such as Canadian Long Island Petroleums have clearly demonstrated that, despite the absence of privity of contract, a purchaser who acquires a property subject to a ROFR without the ROFR rights being dealt with can find itself the subject of an action brought by that ROFR holder, usually for specific performance of the ROFR. ${ }^{45}$

Depending on the circumstances, either the vendor or the purchaser may have conducted an evaluation of the property which could provide some insight into a proper allocation of value, although the ROFR-encumbered properties could be undeveloped properties, mature properties or some combination thereof. Most professional engineering evaluation firms will not normally include upside or potential values for undeveloped properties in their evaluations, although that value is obviously relevant from the purchaser's perspective. In any event, it is normally the purchaser who has developed the bid that has been accepted by the vendor (subject to compliance with the ROFR), and who is therefore likely in the best position to allocate an appropriate value to the relevant property.

In this circumstance, fair market value is not necessarily of particular, or even any, relevance; a wide range of values could be attributed to a particular ROFR-encumbered property by different parties based on their different assessments of the upside potential associated with undeveloped properties, or even the development potential for mature properties. The ROFR holder's perception of fair market value may not be even remotely close to the purchaser's notion of such value, i.e., what it would have been prepared to pay for the property if it was sold on a stand-alone basis. Moreover, there may be a value enhancement resulting from the package deal that would not otherwise exist, such as access to processing facilities and the like. Nonetheless, the necessary exercise that must be undertaken is to develop a fair and supportable allocation of value to the ROFR-encumbered properties to be able to resist any challenge to the ROFR notice by the ROFR holder based upon the issue of consideration. 
Generally speaking, the purchaser's allocation for ROFR purposes tends to prevail, subject to whatever means of control the vendor has retained to protect its interests and obligations to the ROFR holder. It is imperative that the purchaser have well documented and supportable valuations of all properties being acquired, including the ROFR-encumbered properties, as it is obvious that the overall allocation should normally add up to the transaction purchase price. If it does not, there may be a legitimate basis for a ROFR holder to successfully argue that the vendor and purchaser have "loaded up" the value attributed to the ROFR-encumbered property as a means of dissuading the ROFR holder from exercising its ROFR.

If proper documentation regarding property values exists, including assessments of any upside potential which supports the purchaser's conclusions in this regard, then success on any challenge that might be made by the ROFR holder on this issue would be far more difficult to achieve. In most circumstances, it will be of no use to the vendor and purchaser to suggest that no allocation of value has been made to the ROFR-encumbered property. At a minimum, the vendor may well be found to have breached its duty to the ROFR holder by failing to do so. Moreover, the purchaser may, if the transaction has closed without the ROFR obligation being satisfied, be exposed to remedies by the ROFR holder based on the principles developed in the Canadian Long Island Petroleums and succeeding cases, as discussed further below. ${ }^{46}$ Obviously, there is considerable risk for the vendor and purchaser in this scenario if this allocation is not made fairly.

From the perspective of the ROFR holder, it will not suffice to simply argue that the allocated price does not in its view represent fair market value. While that may provide an indication that the allocation has been unfairly made or "loaded up," that alone will certainly not be conclusive. The ROFR holder will have to demonstrate on the evidence that the allocation principles applied by the purchaser and accepted by the vendor were unreasonable in the circumstances, or in other words that a duty of good faith has been breached.

At a practical level, an action challenging a ROFR notice on these or any other justifiable grounds could delay the closing of the purchase and sale of the ROFRencumbered lands, and may even jeopardize the transaction as a whole. Given that there could also be legal consequences for a ROFR holder in this situation, it needs to be quite sure of its position before initiating an action challenging the bona fides of the transaction, as it may find itself as a defendant in an action or a counterclaim if there is some basis for concluding that the only (or at least a significant) purpose to the ROFR holder's action is to thwart the deal. In other words, the ROFR holder itself must not demonstrate a lack of good faith. 


\section{B. CONTENT OF THE NOTICE}

One problem frequently encountered in oil and gas transactions involves the amount of information to be included in the relevant disposition notice by the disposing party. This issue is particularly relevant where properties subject to the 1974 and 1981 CAPL Operating Procedures are involved. These forms provide that "[t]he selling party's notice shall contain the terms and conditions of the proposed assignment, sale or disposition, including the consideration to be received for the subject interest and, if applicable, the name of the offering party." 47 As an initial comment, having recognized that one of the underlying rationales for negotiating ROFRs in the first instance is to permit the ROFR holder to maintain a degree of control over who its working interest co-venturers are, it is difficult to conceive of circumstances under which the name of the offeror would not be "applicable."

On a broader scale, the practice in the industry seems to have evolved such that only the most basic terms, such as the name of the offeror, the description of the interest, the price to be paid and allocations thereof among the properties, adjustments, the effective date and the anticipated closing date are included in the notice. Several authors ${ }^{48}$ have suggested that it is arguable that such notices do not comply with the requirement to disclose "the terms and conditions" of the offer, and that the surest way to ensure compliance with the notice requirements is to enclose a copy of the actual offer to purchase with the notice. It has also been suggested that, in this era of complex and multi-faceted transactions, one should be able to delete provisions which do not refer to "the proposed assignment, sale or disposition" without failing to comply with the requirements of these CAPL forms. ${ }^{49}$ This position may be effective but, to our knowledge, neither it nor any other alternative as to what might effectively constitute "the terms and conditions of the proposed assignment, sale or disposition" have been judicially considered. It is likely a requirement that the words "the terms and conditions" mean "all terms and conditions," since the ROFR holder will be able to insist on full compliance with the requirements of the ROFR clause so that it can make an informed decision as to whether or not it wishes to exercise the ROFR.

The 1990 CAPL Operating Procedure attempts to remove the uncertainty associated with the 1974 and 1981 forms by specifying four terms ${ }^{50}$ which must be included in the notice, with the proviso that the notice must also contain "any other information respecting the transaction which the disposing party reasonably believes would be material to the exercise of the offerees' rights hereunder." ${ }^{51}$ An interpretation of this

1981 CAPL Operating Procedures, Art. XXIV.

See K.T. Smith \& S.H.T. Densted, "Pre-emptive Rights and the Sale of Resource Properties: Practical Problems and Solutions" (1992) 30 Alta. L. Rev. 57 at 85-86; see also Mills \& Beck, supra note 22 at 32.

1990 CAPL Operating Procedure, Art. XXIV. The four terms required to be included in the notice are "a description of the interest proposed to be disposed, the identity of the proposed assignee, the price or other consideration for which the disposing party is prepared to make such disposition [and] the proposed effective date and closing date of the transaction."

Jbid. 
requirement obviously turns on what would be reasonable according to the facts of each particular transaction. Although this test is an objective one, the authors suggest that the conflicting interests of the three parties involved render it difficult, if not impossible, for the vendor to be completely objective when preparing the notice. Therefore, a prudent vendor should adopt the approach that all terms and conditions in the agreement of which it would want to be advised if it were the ROFR holder should be included in the notice.

In an attempt to address the disclosure issue, many disposing parties include in the notice the minimum information stated to be required, and also state a time and location where a copy of the agreement will be made available for review by the ROFR holder. While this may not represent full compliance with the requirements of the ROFR notice, it does appear to represent a reasonable compromise which should permit the ROFR holder to avail itself of all relevant information, and the ROFR holder should not be heard to later complain if it did not take advantage of the opportunity to review the agreement as being representative of what it will be expected to sign to conclude a purchase resulting from any exercise by it of the ROFR.

\section{ACCEPTANCE BY THE ROFR HOLdER}

An additional issue which occasionally arises concerns the manner in which a ROFR holder wishing to exercise its right notifies the vendor of its acceptance. Sometimes, whether intentionally or otherwise, a recipient of a notice responds to the notice in language which leaves the vendor unclear as to whether or not the ROFR holder has exercised its ROFR. These "acceptances" can cause significant confusion and result in unnecessary expenditures of additional time and money. In addressing this problem, a common mistake made by vendors is that they simply provide a notation at the end of the notice, in the manner which has become standard in the industry, for the recipient to sign, indicating that it has either elected or has not elected to exercise or to not exercise its ROFR. ${ }^{52}$ However, the relevant ROFR provisions usually do not stipulate that the only acceptable form of acceptance is by returning a signed copy of the notice with the election noted thereon.

As a result, a recipient who wishes to be intentionally vague might choose to prepare its own form of response, without being in violation of the requirement of strict compliance with the ROFR clause. A party proceeding in this manner potentially does so at its own risk as it could be later determined that no effective election in response to the ROFR notice was made. In such circumstances, the ROFR holder will have lost the acquisition opportunity and the purchaser whose offer triggered the ROFR may also have a claim against the ROFR holder. Therefore, the authors recommend that where possible, the only acceptable form of response to the ROFR notice be clearly defined in the ROFR clause, and that the ROFR notice be issued accordingly. While one could provide in a ROFR notice that no form of response other than a signed copy of the ROFR notice itself clearly indicating the election being made will be considered acceptable, clear language having that effect would be necessary. 


\section{ABSOlute OR CONDITIONAL OFFer?}

A further issue involves whether or not the election by the ROFR holder to purchase the property described in the ROFR notice on the terms and conditions contained in that notice creates a binding and enforceable contract of sale between the ROFR holder and the vendor which remains in effect notwithstanding that the vendor might decide it no longer wishes to sell the property at all. In Budget Car Rentals, ${ }^{33}$ the Ontario Court of Appeal considered whether a ROFR constituted an agreement separate and distinct from the contract in which it is located. The court addressed this issue in the context of a ROFR included in a lease, which also contained an automatic renewal provision. The court held that although a ROFR does not require separate consideration from that given for the agreement in which it resides, it is nevertheless an agreement separate and distinct from the main agreement.

The case of Wyssling Estate v. Latreille Estate ${ }^{54}$ supports the proposition that a ROFR triggered by a party's willingness to sell its interest under the main agreement creates an option in favour of the ROFR holder to purchase the land notwithstanding that the vendor took no further steps towards selling the property. It has been suggested that the preferable view is that an exercised ROFR creates an agreement between the vendor and the ROFR holder which cannot be defeated by the purchaser's decision to withdraw. ${ }^{\text {ss }}$ This position is based on at least two main arguments: (1) most ROFR clauses provide that the ROFR is triggered upon the vendor's willingness to sell and not on its receipt of an offer, and (2) to maintain otherwise would provide an unscrupulous vendor and purchaser the opportunity to conspire to defeat the interest of the ROFR holder. This view appears to be an appropriate statement of the law in effect in Canada at the present time. To achieve a different result, appropriate language would have to be incorporated into the relevant ROFR provisions.

\section{AdDITIONAL KEY ISSUES}

\section{A. Package Sales}

Multi-property transactions (i.e., where the vendor groups a number of separate parcels together for sale as one "package") are quite common in the Canadian oil and gas industry, which can make assessment of the application of ROFR clauses difficult. Inevitably, the issue arises as to whether this en bloc sale triggers ROFRs attaching to the few individual properties which, if sold separately, would unquestionably trigger such ROFRs. Unfortunately, there is very little guidance available from the Canadian courts on the issue, and what little is available does not involve multi-property oil and gas transactions, which undoubtedly represents the area standing to benefit the most from some judicial guidance given the current popularity of these types of transactions and the high values of the properties involved. 
There are a number of U.S. cases which deal directly with this issue and, as one commentator has observed, ${ }^{36}$ virtually all of these cases have rejected the argument that ROFRs are not triggered in multi-property transactions because no offer exists for the ROFR encumbered property alone. However, one of the first authoritative Canadian cases which dealt with this issue came to a completely contrary conclusion. In Budget Car Rentals, ${ }^{57}$ the purchaser, Petro-Canada Inc. ("Petro-Canada"), purchased from the vendor, Gulf Canada Limited ("Gulf"), the vendor's entire marketing and refinery operations in all provinces west of Quebec. The transaction involved several hundred properties at a total purchase price of over $\$ 300$ million, and individual values out of the total purchase price were not allocated by Gulf and Petro-Canada amongst the individual properties. The plaintiff occupied one of these properties under a lease which contained a standard ROFR clause providing the plaintiff with an option to match any "bona fide offer" to purchase the leased premises which the lessor was "willing to accept." 58 In its decision, the Ontario Court of Appeal held that because the parties had not assigned separate values to the individual parcels, Gulf had not received a bona fide offer to purchase the subject property and, as a result, the ROFR attaching to it was not triggered. Calling this analysis "difficult to support," 39 Flannigan observed as follows:

The issue was whether the transaction which occurred involved a dealing with the subject property such that it could be said that a sale had taken place. According to the terms of the right of first refusal, it was triggered if "the Lessor receives a bona fide offer to purchase the lands and premises herein, which it is willing to accept." This language is typical of that found in the American cases spread over the last fifty years, in almost every one of which the court concluded that the package disposition violated the right of first refusal..$^{60}$

This case has not been widely accepted or supported on this point and, for the same reasons set out above, the authors agree with the comment that it would not likely be followed in the context of a multi-property oil and gas transaction without considerable justification based on special facts. ${ }^{61}$

A subsequent case out of Ontario, Municipal Savings \& Loan Corp. v. Oswenda Investments Ltd. ${ }^{62}$ involved a block sale of six properties for a single price of $\$ 2,275,000$. A lease previously granted by the vendor in respect of one of the six parcels contained a standard ROFR clause, and the parties made no allocation of the total price among the six parcels. The court in this case distinguished the decision in Budget Car Rentals on the basis of the vastly different dynamics necessarily involved in that much larger transaction. Nevertheless, the court still ended up, perhaps unwittingly, adopting an element of the approach taken in Budget Car Rentals and held that there was no evidence on the facts of a willingness on the part of the vendor to sell

Flannigan, supra note 24 at 29.

Budget Car Rentals, supra note 13.

Ibid. at 752.

Flannigan, supra note 24 at 34.

lbid. See also Mills \& Beck, supra note 22 at $48-49$.

Mills \& Beck, ibid. at 49.

(1989), 7 R.P.R. (2d) 196 (Ont. H.C.J.) [hereinafter Oswenda]. 
the property on its own given that, inter alia, no price was fixed for the property in question. Accordingly, the court held that the ROFR was not triggered and therefore no option to purchase the property arose in favour of the plaintiff. The court did find, however, that the plaintiff's personal rights under the ROFR were "effectively rendered nugatory" by the transaction as it was structured and awarded damages for interference with these rights. ${ }^{63}$

In the case of Associated Graphic Supplies Ltd. v. B. \& L. Properties Development $L t d^{64}$ the British Columbia Supreme Court appeared to approve the decision of the chamber judge that the vendor was in breach of contract by failing to assign a price to the property subject to the ROFR. The package sale in issue involved just three parcels, one of which was subject to a lease containing a ROFR in favour of the tenant. The ROFR in question was of substantially the same form as in the two preceding cases, but notably contained a slightly more detailed clause requiring the vendor to set out the purchase price offered for the property in addition to the more standard language requiring disclosure of the "terms and conditions of the offer." The court noted from the chambers decision that the landlord had "an obligation not to accept an offer for the three lots as one parcel," and was in breach of contract "by failing to set out or being in any position to set out a specific price and terms for the sale of [the subject property]." ${ }^{365}$ Damages for breach of contract, but not specific performance, were granted to the ROFR holder.

Obviously, the cases discussed above do not arise in the context of oil and gas related transactions, and therefore a certain extrapolation of analogous facts is sometimes necessary. However, as they constitute the only guidance presently available from the Canadian courts, it is important that the principles involved be thoroughly understood. The trend of these decisions is to find that a disposition of a property as part of a larger package in the face of an applicable ROFR is a violation of the contractual rights of the ROFR holder and can lead to an award of damages for interference with those rights. Where the language of the ROFR clause is sufficiently clear, damages for breach of contract may also be available. This approach follows a consistent line of American jurisprudence and rejects the ratio of the Budget Car Rentals case.

\section{B. Unmatchable Consideration}

The title of this section suggests a problem which has often surfaced in the context of ROFRs, namely that the consideration stipulated in the offer which triggers the ROFR is not limited to money alone. When presented with such an offer, the holder of a typical ROFR is faced with a difficult dilemma. In order to satisfy the requirements of strict compliance discussed above and properly exercise its pre-emptive right of purchase, it must agree to purchase the property on the same terms and conditions as contained in the original offer, which in the circumstances may be impossible. 
With respect to offers along these lines involving oil and gas properties, two distinct paths of analysis are required. First, where the ROFR in question is one found in Article XXIV of the CAPL Operating Procedures, the proposed vendor may set out in its notice to the holder of the ROFR its bona fide estimate of the cash value of the unmatchable consideration in satisfaction of its obligations. If the proposed purchaser neglects or refuses to include this estimate in the ROFR notice, then the holder of the ROFR may request this estimate, and any disputes as to its reasonableness may be referred to arbitration.

It should be noted that the CAPL procedures differ on two important points. ${ }^{66}$ First, the 1974 and 1981 CAPL Operating Procedures provide that the holder of the ROFR has a period of twenty days after receipt of the notice to elect to exercise its rights. However, both of these procedures expressly provide that if the issue of the reasonableness of the estimated cash equivalent is referred to arbitration, "the notice period shall not be extended by such referral of the dispute to arbitration." Since the ROFR holder cannot be certain that it would be able to refer the dispute to arbitration and obtain a decision by the arbitrator within the specified twenty-day period, the practical effect of this is to require the holder of the ROFR to elect within this period based on the numbers supplied by the proposed vendor. However, where a dispute is referred to an arbitrator pursuant to either the 1974 or 1981 CAPL Operating Procedures, the equivalent cash consideration payable by the ROFR holder is the lower of the estimate provided by the proposed vendor and the amount determined by the arbitrator.

Significant departures from both of these procedures were implemented in the 1990 CAPL Operating Procedures. In short, under this procedure, the notice period is thirty days from receipt of the ROFR notice if there is no dispute as to the amount of the equivalent cash consideration. However, if the matter is referred to arbitration, the notice period is suspended until the arbitration is completed (presumably in accordance with another new requirement in the 1990 form that the parties "diligently attempt to complete such arbitration in a timely manner"), and the ROFR holder has fifteen days from receipt of the arbitrator's decision to elect to exercise its right. However, under this procedure, the amount determined by the arbitrator is the amount payable by a ROFR holder who elects to exercise, even where this value is higher than the proposed vendor's original estimate.

We now emerge out of the relative clarity of the CAPL Operating Procedures to a situation of comparative obscurity. Until recently, it was fairly settled law in Canada that a proposed vendor had a duty at common law to state an equivalent cash value for any non-cash consideration which it was willing to accept. This principle was established in Manchester ${ }^{67}$ and remained unchallenged until the recent decision of the Ontario High Court of Justice in Baggots Brass Beds Ltd. v. Neal Leasing Inc. ${ }^{68}$ In Baggots, a property was subject to a lease which contained a ROFR in favour of the

68 (1989), 4 R.P.R. (2d) 316 (Ont. H.C.J.) [hereinafter Baggots]. 
lessee and the owner of the property accepted an offer from a third party to purchase the land. The language of the ROFR clause in question was fairly standard in that it gave the lessee the option to purchase the leased premises on the same terms and conditions of any offer to purchase received by the lessor and which the lessor was prepared to accept. The offer to purchase included, as part of the consideration for the sale, a parcel of land owned by the proposed purchaser which was highly desirable to the vendor as a location for its business, and the offer further provided that the value of the property being received was $\$ 500,000$ for the purposes of calculating the total purchase price of $\$ 1,125,000$. The lessor sent a notice to the lessee which advised that it had accepted the offer and suggested that the ROFR was likely not exercisable and that the notice was being sent simply "as a matter of complying with the provisions of the Lease. ${ }^{169}$ The tenant replied by claiming that the ROFR remained in full force and served notice that it was ready and able to exercise its option to purchase the property for the total purchase price of $\$ 1,125,000$ as stated in the offer. It also commenced proceedings to restrain the sale to the proposed purchaser and later attempted to tender the full amount of the purchase price to the vendor in compliance with the terms of the ROFR, but this payment was refused.

In his decision, Southey J. found that the offer of cash and land by the proposed purchaser was made in good faith and that the ROFR had not been validly exercised by the tenant. He arrived at this conclusion apparently without considering the Manchester decision and instead referred to a U.S. case which followed a fairly long line of U.S. authorities on this point. The substance of his reasoning is best understood by an excerpt from the U.S. decision which he quoted in the text of his judgment:

The right holder is entitled to a fair opportunity to meet the conditions of a third party offer if the property owner decides to sell. If the right holder meets those terms, he or she is entitled to purchase the property.

Offers which arguably leave the property owner "as well off" as does the third party offer, but which vary materially from it, render the purported acceptance a counteroffer. Northwest TV, $26 \mathrm{Wn}$. App., at $118612 \mathrm{P} 2 \mathrm{~d} 422$.

Allowing a cash offer to be the equivalent of the property exchange offer, regardless of the factual situation, imposes a different contract on the parties and seriously infringes on the owner's right to dispose of the property. There is a middle course. By implying a duty of reasonableness and good faith in property exchange offers we adopt a course which protects the interest of both the property owner and the holder of the right. ${ }^{n}$ 
Southey J. accepted the lessor's evidence that the property tendered as being partial consideration was of particular strategic value to it and that it would not have accepted this offer at the total price stated if the property had not formed part of the consideration. This fact satisfied Southey J.'s requirement of "reasonableness and good faith." He also noted that the tenant had not made any attempt to acquire the land in question in order to be in a position to strictly comply with the terms of the ROFR. Further, Southey J. pointed out that the tenant had failed to tender the same deposit which the proposed purchaser tendered at the time it made the offer, which failure he considered particularly fatal to the tenant's purported exercise of the ROFR.

In reaching this conclusion, Southey J. assumed "that these reasonable [American] propositions are also the law of Ontario," or that, "[i]f not, I am sure that our law would not be more favourable to the holder of a right of first refusal."71 However, at least one author ${ }^{72}$ has severely criticized the decision in Baggots and, in so doing accurately summarizes the uncertainty which, as a result of this decision, now appears to exist in respect of this issue:

These remarks amount, however, to little more than a guess. The issue is plainly somewhat more difficult than Southey J. believed. There are plausible arguments supporting both positions. The problem of immediate concern is the uncertainty that now exists over what constitutes the default rule in Canada. Essentially, because the authorities conflict, there is currently no rule, resulting in the loss of any efficiencies associated with the existence of an ascertainable default position. The strategic implication is that it is for the party to whom it matters to explicitly negotiate how mixed or non-cash offers will be handled."

\section{REMEDIES}

At this point, it is appropriate to discuss the remedies which could be available to a holder of a ROFR who feels that its rights are being, or have been, infringed by the parties to a sale transaction. The four principal remedies available in such circumstances (declarations, interim injunctions, specific performance and damages) are discussed below.

\section{A. Declarations}

In the circumstances described above, generally a party should seek declaratory relief in addition to whatever substantive relief is also being sought. A declaration is a judicial statement amounting to neither more nor less than a confirmation or denial by the court of the legal rights being asserted by the applicant. All Canadian common law provinces and the federal government have enacted legislation which confirms the availability of declaratory judgments in their jurisdictions, with statutory language identical or substantially similar to the following:

" Baggots, ibid. at 322.

$7 \quad$ Flannigan, supra note 24 at 13-14. See also Mills \& Beck, supra note 22 at 45-47.

3 Ibid. [emphasis in original, footnotes omitted]. 
No action or proceeding shall be open to objection on the ground that a merely declaratory judgment or order is sought thereby, and the court may make binding declarations of right, whether or not any consequential relief is or could be claimed. ${ }^{74}$

In an action advancing claims under a ROFR, the plaintiff should plead for a declaration as to the applicability and effect of that particular ROFR.

\section{B. INJUNCTIONS}

\section{The TRIPARTITE TeSt}

Injunctive relief is an equitable remedy which, in most provinces, requires that the party seeking the remedy meet a tripartite test. ${ }^{75}$ The basis for this test was first set out in American Cyanamid Co. v. Ethicon Ltd. ${ }^{76}$ The three requirements which must be met for this test to be satisfied are:

(1) there must be a serious issue to be tried;

(2) irreparable harm to the applicant would result if an injunction is not granted (i.e., no other fair and reasonable remedy would exist); and

(3) the balance of convenience must favour the granting of the injunction. ${ }^{77}$

In determining whether the plaintiff meets the requirements of this tripartite test, the court will consider each element of the test, and a failure to meet any one of these parts of the test will prevent the injunction from issuing.

\section{a. Serious Issue to be Tried}

The Supreme Court of Canada has determined that a "prolonged examination of the merits is generally neither necessary nor desirable" at this level of the analysis. ${ }^{78}$ Once the court is "satisfied that the application is neither frivolous nor vexatious," the court will generally consider that this requirement has been met and will move on to a consideration of the second and third tiers of the test. ${ }^{79}$ However, there have been

L. Sama, The Law of Declaratory Judgments, 2d ed. (Toronto: Carswell, 1988) at 5. In Alberta, this provision is slightly modified and may be found in the Judicature Act, R.S.A. 1980, c. J-I, s. 11. For a complete list of the various Canadian statutes where this provision may be found, see note 1 in Sama, ibid.

In Alberta, this test was adapted to a tripartite sequential test by the Alberta Court of Appeal in both Law Society of Alberta v. Black, [1984] 6 W.W.R. 755 and Ominayak v. Norcen Energy Resources Lid. (1985), 36 Alta. L.R. (2d) 137 [hereinafter Ominayak], wherein the court held that each element of the test must be satisfied in sequence, failing which the injunction cannot issue. [1975] All E.R. 504 (H.C.) [hereinafter American Cyanamid].

lbid. at 505.

R.J.R. MacDonald Inc. v. Canada (Attorney General), [1994] 1 S.C.R. 311 at 338.

Ibid. at 337. 
instances where this requirement was not met, so one should not assume that it will be satisfied in all but the most obviously frivolous actions.

\section{b. Irreparable Harm}

In Alberta, the leading authority on this principle is Edmonton Northlands $v$. Edmonton Oilers Hockey Corp. ${ }^{80}$ In this case, the court confirmed the statement made by Lord Diplock in American Cyanamid that the first consideration under this branch of the test is whether the plaintiff can be "adequately compensated in damages." ${ }^{81}$ In Ominayak, Cairns J.A. held that irreparable harm means more than being beyond the possibility of redress by money damages; rather, he held that it must be "harm for which no fair and reasonable redress would be available after trial."

Somewhat recently, an exception to the requirement of demonstrating irreparable harm has developed out of the Alberta Courts. In the most recent of these cases, Debra's Hotels Inc. v. Lee, ${ }^{83}$ the court dealt with an application for injunctive relief by a plaintiff that held a restrictive covenant registered against land occupied by the defendant which restrained this land from being used for a "sit-down restaurant." Notwithstanding the existence of this restrictive covenant, the defendant entered into a lease with a tenant to open a forty-seat coffee and sandwich bar within premises located on these lands. Referring to two earlier decisions of the Alberta Court of Appeal, ${ }^{84}$ the court noted that "irreparable harm need not be established if there is a clear breach of a clear covenant." ${ }^{85}$ The court held that, absent a definition in the restrictive covenant of the words "sit-down restaurant" and in the absence of the original contracting parties, "a common sense approach should be taken to ascertain the meaning of these words." ${ }^{16}$ On this basis, the court found that the proposed coffee and sandwich bar clearly constituted a "sit-down restaurant". and held that this exception to the requirement of demonstrating irreparable harm applied in the circumstances. The court ultimately determined that the balance of convenience (to be discussed below) also lay with the plaintiff and, in the result, granted the injunction.

As a final comment on this point, it is worth noting that in both Canada Safeway Lid. v. Excelsior Life Insurance Co ${ }^{87}$ and West Edmonton Mall Lid. v. McDonald's Restaurants of Canada Ltd., ${ }^{88}$ the Alberta Court of Appeal set aside injunctions which had been issued out of the Court of Queen's Bench where the lower court had relied substantially on this exception in issuing both injunctions. Obviously, therefore, one court's interpretation of what constitutes a "clear breach of a clear covenant" will not

(1994), 17 Alta. L.R. (3d) 382 (C.A.), affg (1993), 15 Alta L.R. (3d) 179 (Q.B.).

Jbid. at 193.

Ominayak, supra note 75 at 145 .

(1994), 24 Alta L.R. (3d) 199 (Q.B.) [hereinafter Debra's Hotels].

Canada Safeway Lid. v. Excelsior Life Insurance Co. (1987), 55 Alta. L.R. (2d) 120 (C.A.) and West Edmonton Mall Lid. v. McDonald's Restaurants of Canada Lid. (1993), 141 A.R. 266 (C.A.).

Debra's Hotels, supra note 83 at 204.

Ibid. at 207.

Supra note 84.

Ibid. 
necessarily be shared by a higher court on appeal and this exception should not be considered to be as readily applicable to the interpretation of ROFRs as one might otherwise be tempted to believe, especially where there is any level of ambiguity in the language of the ROFR clause.

In this article, the authors have not attempted to engage in a detailed analysis of the various factors which the courts may consider in determining whether there has been a "clear breach of a clear covenant." For present purposes, the clearer the language of the ROFR covenant in question is, the more comfortable the court will be in determining that the covenant has in fact been breached. This conclusion alone should be viewed as reason enough to justify taking the additional time and incurring the expense required to draft a ROFR clause which properly and effectively addresses the types of transactions and the related issues that may reasonably be expected in the future.

\section{c. Balance of Convenience}

This final element of the tripartite test requires the court to balance the relative effect that the granting or withholding of the injunction will have on the parties. Some of the factors which the court will take into account when considering this question includes the relative level of harm which each party will suffer as a result of the issuance or non-issuance of the injunction, the comparative merits of each case and other special factors such as, for example, whether a corporation is likely to fail as a result of the court's decision. Also, if a plaintiff is unable to give the required undertaking to account to the defendant for damages resulting from the injunction, this failure may tip the scales of this portion of the test against the plaintiff.

Generally, there is no exception available for this final element of the test for injunctive relief. However, in Debra's Hotels the court noted that "a consideration of balance of convenience necessarily engages the matter of harm," and that "from a practical point of view, the balance of convenience test would indeed be softened were a restrictive covenant breach at issue." ${ }^{19}$

\section{INJUNCTIONS AND ROFRS}

Where the possibility of defeating an interest in land is at issue, the courts are generally more inclined to be receptive to an argument that a loss of this right, whether by conveyance of the subject property to a third party or otherwise, constitutes irreparable harm. As a result, where interests in land are involved, an injunction is likely easier to obtain compared to, for example, an action involving shares or other personal property. Although they are now deemed to be interests in land in some provinces, even prior to the triggering event, and at common law after the triggering event has occurred, ROFRs do not necessarily benefit from similar treatment. This fact 
was evidenced in a decision of the Saskatchewan Court of Queen's Bench ${ }^{90}$ involving a dispute over the applicability of a ROFR involving Saskatchewan Oil \& Gas Corporation ("Saskoil"), Mobil Oil Canada Ltd. ("Mobil Oil") and North American Life Assurance Company ("North American").

In this case, Saskoil applied for an interim injunction restraining Mobil Oil from disposing of certain lands pending the outcome of the action. Saskoil's position was that Mobil Oil was in the process of selling the lands to North American in violation of a ROFR held by Saskoil under a joint venture agreement. At issue was whether the ROFR applied to unitized lands as well as non-unitized lands." To summarize the facts briefly, Mobil Oil put the lands governed by the joint venture agreement between itself and Saskoil out for public tender. After some internal deliberation, Mobil Oil concluded that the ROFR applied only to the non-unitized lands and sent Saskoil a ROFR notice with respect to these lands, which Saskoil exercised. However, Saskoil did not accept Mobil Oil's interpretation of the ROFR clause and refused to bid on the unitized lands on the basis that the ROFR properly applied to these lands as well. North American submitted a bid for the unitized lands which Mobil Oil accepted, and these two parties proceeded towards ultimately closing the purchase and sale transaction. Saskoil then applied for an injunction restraining Mobil Oil from disposing of the lands.

The court concluded that Saskoil failed even to meet the first test of whether there was a serious issue to be tried, finding that no serious issue arose out of the language of the ROFR clause in question. The court pointed out that, although it was unnecessary to consider the second and third tiers of the test, because of the "strict record-keeping requirements of both the Plan of Operation and the terms of the [purchase and sale agreement], should [Saskoil] ultimately be successful, any damage it may have suffered will be calculable." 92

It would appear from this dicta that a party applying for an injunction restraining the sale of an oil and gas property pending judicial interpretation of the applicable ROFR clause could face considerable reluctance on the part of the court to intervene, given that the applicant's interest in the lands is, by definition, purely financial and may be compensable in damages. ${ }^{93}$

Saskatchewan Oil \& Gas Corp. v. Mobil Oil Canada Lid. (1989), 81 Sask. R. 31 (Q.B.) [hereinafter Saskoi]].

See the discussion in section III.B.3 ("ROFRs in Underlying Agreements").

Saskoil, supra note 90 at 35 .

Several cases have taken the approach that transactions where lands are being purchased for investment purposes are not proper candidates for specific performance. See, e.g. Heron Bay Investments Lid. v. Peel-Elder Developments Lid. (1976), 2 C.P.C. 338 (Ont. H.C.J.) and Chaulk v. Fairview Construction Ltd. (1977), 14 Nfld. \& P.E.I.R. 13 (Nfld. C.A.). 


\section{Specific Performance}

As is the case with the remedy of injunctive relief discussed above, a grant of specific performance is in the discretion of the court. ${ }^{\text {gt }}$ It has long been established that one of the prerequisites required to convince a court to exercise its discretion in favour of granting this remedy is that the plaintiff must establish that the purchaser who acquired the lands in violation of the ROFR did so with notice of the covenant. This principle was confirmed in Canadian Long Island Petroleums ${ }^{95}$ and is consistent with the sacred principle at the heart of the Torrens land titles system, namely that a bona fide purchaser for value and without notice or fraud, who first registers its interest, has priority over prior unregistered and subsequently registered interests. In Canadian Long Island Petroleums, specific performance was awarded as against both the vendor and the third party purchaser due in large measure to the fact that the purchaser acquired title to the lands with knowledge of the existence of the ROFR to which the lands were subject. In his decision, Martland J. stated that: "[i]n equity the covenant bound the appellant Long Island unless it could establish, as clearly on the evidence it could not, that it had obtained title without notice of the covenant."${ }^{.96}$

In Hawker Siddeley, ${ }^{97}$ the court awarded specific performance, requiring one party to a shareholders' agreement containing a ROFR to sell its shares in a jointly owned subsidiary corporation to the other party to the shareholders' agreement. As was discussed in more detail above, the vendor had entered into a series of step transactions to convey the shares in questions to a third party through a takeover bid process. The evidence before the court was that these transactions were designed, at least in part, to avoid triggering the ROFR..$^{98}$ Blair J. observed as follows:

It is the contractual entitlement to exercise [the right of first refusal], the wrongful attempt by [the vendor and the proposed purchaser] to circumvent it, and the "oppressive" nature of the conduct in relation to those events, which form the basis for the granting of a remedy in favour of the Applicants. It seems to me that the most suitable remedy is one which rectifies the wrong and the "oppression," and which gives effect to the contractual entitlement. That remedy is a decree of specific performance. 99

There is authority which complements the foregoing analysis and provides that specific performance may not be available in the absence of notice or in circumstances

Note that there is authority out of the Supreme Court of Canada for the proposition that where entitlement to a remedy has been established by a party to an action involving an agreement for the sale of land, specific performance is available "as a matter of course." See Kloepfer Wholesale Hardware \& Automotive Co. v. Roy, [1952] 2 S.C.R. 465 at 472. It is somewhat questionable whether this principle would be upheld today. Supra note 3.

Jbid. at 281.

Supra note 29.

A key factor in this case which the court emphasized in awarding specific performance, but which is not germane to the discussion of rights of first refusal attaching to interests in real property, is that the court found that the directors of the vendor acted in an "oppressive" manner pursuant to the terms of s. 241 of the Canada Business Corporations Act, supra note 23.

Hawker Siddeley, supra note 29 at 295-96. 
amounting to bad faith. In Island Properties Ltd. v. Entertainment Enterprises Ltd., ${ }^{100}$ the defendant made an offer to sell land to the plaintiff which was accepted. The defendant later took the position that the plaintiff's acceptance of the offer was invalid and executed a conveyance of the land in question to a third party who was unaware of the proposed transaction between the plaintiff and the defendant. The court held that the plaintiff was not entitled to specific performance as it was not able to establish that the third party purchaser had acted in bad faith. However, the court found that the defendant was liable to the plaintiff for damages.

Clearly, the courts have indicated that, in the appropriate circumstances, specific performance is available as a remedy to enforce a ROFR clause. Moreover, it would likely be a rare circumstance in the oil and gas industry where a prospective purchaser has not been provided with copies of, or at least been given access to, all applicable agreements for review, including the one which provides for the ROFR. This would make it very difficult for a purchaser to argue in such circumstances that it is a bona fide purchaser without notice of the ROFR in order to avoid an award of specific performance being issued against it in relation to a property it has acquired without the ROFR provisions having been complied with.

\section{Damages}

Obviously, a ROFR holder would seek damages against the vendor and the purchaser as an additional protective measure in the event that the other remedies potentially available to it are not successful. Damages might be sought against the vendor for breach of contract (i.e., breach of the ROFR clause). Damages might also be sought against the purchaser for inducing breach of contract and for interference with economic relations (a quasi-contractual tort) and perhaps also (along with the vendor) for civil conspiracy to effect this wrongful conduct. Punitive damages, although rarely awarded, might also be sought against the vendor or the purchaser or both for intentional breach of contract.

An interesting issue is raised in relation to damages as a result of the decision in Oswenda $a^{101}$ discussed above. In that decision, the court concluded (some would say erroneously) that the ROFR properly contracted for between the plaintiff and the defendant was effectively extinguished and rendered void by a block sale of lands (which included the lands subject to the ROFR) to a third party purchaser. Having decided that the ROFR was extinguished, the court found that specific performance was unavailable as a remedy. Moreover, the court also found that the "holder" of the neutered ROFR was not entitled to damages against the third party purchaser for inducing breach of contract, as there was no evidence of this tort before the court. However, the court did award damages for interference with the plaintiff's ROFR. This rationale suggests that a ROFR has an ascertainable and calculable value independent of the resulting purchase transaction for which compensation might also be granted. 


\section{Conclusions}

One unavoidable conclusion from the foregoing analysis is that there is a dearth of helpful Canadian jurisprudence with respect to many of the issues involved in the interpretation and construction of rights of first refusal. However, in relation to some of the issues involved, certain concepts and principles seem quite clear. Specifically, the Canadian courts will likely employ a broad, purposive approach to determining whether a ROFR attaches to a particular property in the context of a particular transaction. But, these same courts will then construe ROFR clauses strictly according to their terms, treating them as being in the nature of options, which they clearly represent once a triggering event has occurred.

For owners of oil and gas properties subject to ROFRs and other pre-emptive rights, certain other implications are equally clear. Given the potentially disastrous consequences involved, a party faced with the prospect of attempting to assign its interest should comply with the terms of the particular ROFR as precisely as possible in the circumstances. Similarly, a party who receives a notice pursuant to a ROFR which has been triggered should fully comply with the requirements set out in the notice, assuming that it is not inconsistent with or, alternatively, fails to comply with the provisions of the relevant ROFR clause. If either or both of them fail to do so, they will be assuming a significant risk of either having the ROFR notice vacated as not being in compliance, or the purported exercise of the ROFR being declared invalid or ineffective, as the case may be.

Certain exceptions to these principles, and sometimes to the applicability of the ROFR itself, can apply. However, it is unlikely that such exceptions will be available to a party intending to rely on them while attempting to do indirectly what the ROFR prevents it from doing directly. Transactions that are structured with the purpose (or at least one significant purpose) of avoiding the application of ROFRs will likely not stand up under judicial scrutiny. Having said that, it is nonetheless possible for certain transactions, usually corporate restructurings having a sound business purpose other than avoidance of ROFRs, to be completed without such ROFRs becoming operative. In such instances, the ROFR will nonetheless continue to bind the property in question in the face of future transactions involving the property that is otherwise not excepted. In any event, each of the specific ROFR provisions needs to be examined even in these cases to assure effective compliance where appropriate.

The allocation dilemma discussed in this article is very real, and the relevant stakeholders need to proceed cautiously and with due consideration of all of the legal duties, obligations and concerns each of them may have in the particular circumstances. To do otherwise invites problems and potential delays in concluding legitimate transactions, as well as the risk of time consuming and expensive litigation.

Lastly, the authors hope the discussions in this article have underscored the importance of drafting proper ROFR clauses at the outset, in circumstances where the parties have the opportunity to do so and believe them to be appropriate. Many of the issues that are being disputed or that result in litigation may have been reasonably 
foreseeable at the time the parties were entering into the applicable contractual arrangements had they addressed their minds to the potential scenarios that might be involved. As such, it may be that the relevant issues could have been specifically dealt with by proper drafting. Nonetheless, while there always will be unforeseen problems and issues that will be identified after the contractual arrangements are put into effect, appropriate care and attention to what is already known and what can reasonably be expected should go a long way in terms of avoiding the mistakes of those who have gone before. 